\title{
Kosovo one Step Closer to Europe
}

\author{
Phd@ Remzi Smajli \\ Professor, Faculty of Economics, "FAMA" College, Pristina
}

\begin{abstract}
The Republic of Kosovo is a country which is going through transition, and laid the foundations of the democratic system to a free market economy. The developing countries depends heavily on import (report import / export is about $90 \%$ to 10\%). This element is a weight indicator for Kosovo's dependence on other countries.

The Republic of Kosovo is a country which is the official currency in use Euro, and is not part of the eurozone. So Kosovo has stagnated in the exercise of monetary policy, this indicator is the second element of Kosovo, which represents the country's dependence from euro zone countries.

A particular weight in the development of Kosovo these past 15 years have been remittances, which nevertheless faded though year after year continue to have the matter further. The bulk of remittances come from compatriots working and operating in European countries. The third indicator of the greater impact of the euro area economy are precisely the level of remittances.

Field of study in this research work consists precisely these three indicators 1.Raporti import / export, 2.Dependence on the exercise of monetary policy, 3.Remittances.

Cooperation amongst countries is the main element in the XXI century, which characterizes globalization. This model also creates interdependence cooperation amongst the states, and often the inequalities between nations because the rich are the ones that determine the poor, so the fate of the free evolved countries and developing countries depend directly by the strong countries developed countries.
\end{abstract}

Keywords : The Euro zone, economy, Kosovo's economy, globalization

\section{Entry}

Actually increase the independence of national economies can be seen as the culmination of a trend that has begun over a century ago, but the level of recently is unprecedented, since the economies of states are highly related to each other, traditional ideas based around states, currency exchange mechanisms, trade market and are re-examined under a new light.

Political Economy at the international level is becoming increasingly important because it is in the vortex of politics and national economies and the impact of the market economy and developed countries.

A free market stock, which falls in Asia, will spread like a crazy fire in New York and London. Depression out (state) means falling within (state). Inflation shared everywhere and now it looks as insusceptible to the control of any single actor. (CHARLES W. KWGLEY, 2009)

In this correlation values national economies increasingly lose their independence and integrate so compelling in international, global and regional organizations. Such luck though not members in several international organizations, are experiencing even Kosovo as the newest state in Europe.

\section{Western Balkans economy and the Europe}

Global economic activity in 2014 took place in a more relaxed macroeconomic environment. The US economy was characterized by strengthening economic growth, driven mainly by domestic demand, while the euro zone economic recovery finally began despite uncertainties about the eventual consequences of the problems in Greece. Economic activity in the euro area in 2014 is gradually recovering, improving consumer confidence and the gradual improvement in labor market conditions. However, economic growth remained concentrated in central euro zone economy, namely in Germany, while different parts of the euro area continued to be characterized by weak growth, i.e. recession. In 2014, economic growth in the euro zone reached 0.9 percent versus economic decline recorded in the previous year of 0.5 percent. Although still considered modest economic growth, signals for further strengthening of activity in the region of eurozone rely heavily on fall 
further rise in oil prices, which are expected to reflect the growing confidence of consumers and therefore to increased costs.

Also, economic growth is expected to be supported by the continuous increase of the eurozone exports as a result of depreciation of the euro and the start of implementation of the program of quantitative easing from the European Central Bank (ECB). For 2015, the IMF predicts economic growth of 1.5 percent in the eurozone.

According to the ECB, the average inflation rate in the eurozone in 2014 down to 0.4 percent from 1.4 percent in 2013. The continuing decline in prices in the international markets has resulted in a deflation of 0.6 percent or 0.3 percent in January and February 2015.

Performance of economic activity in the Western Balkans in 2014 is estimated to have been generally weaker than in 2013. The slowdown in economic growth in 2014 in the Western Balkans ascribed to weak consumption growth and the deterioration of the position of net exports as a result of weak recovery in demand in the eurozone. Average economic growth in the Western Balkan countries in 2014 is estimated to have been 1.5 percent (2.6 percent in 2013). Higher economic growth in the region marked Macedonia (3.8 percent), while Serbia was the only country in the region that was characterized by economic decline in 2014.

Real growth of $P B B$ in percentage

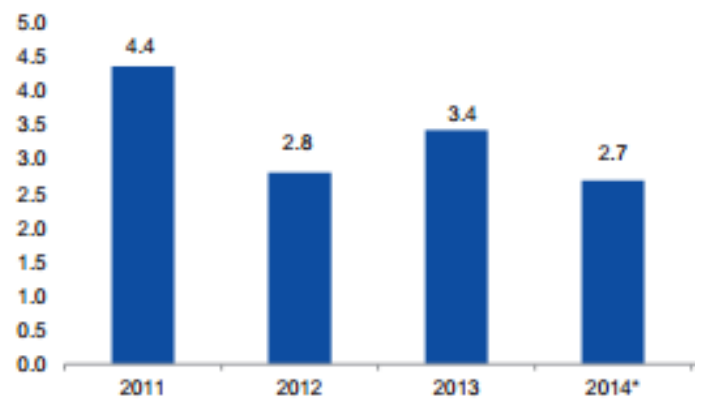

The inflation rate, the annual change in percentage

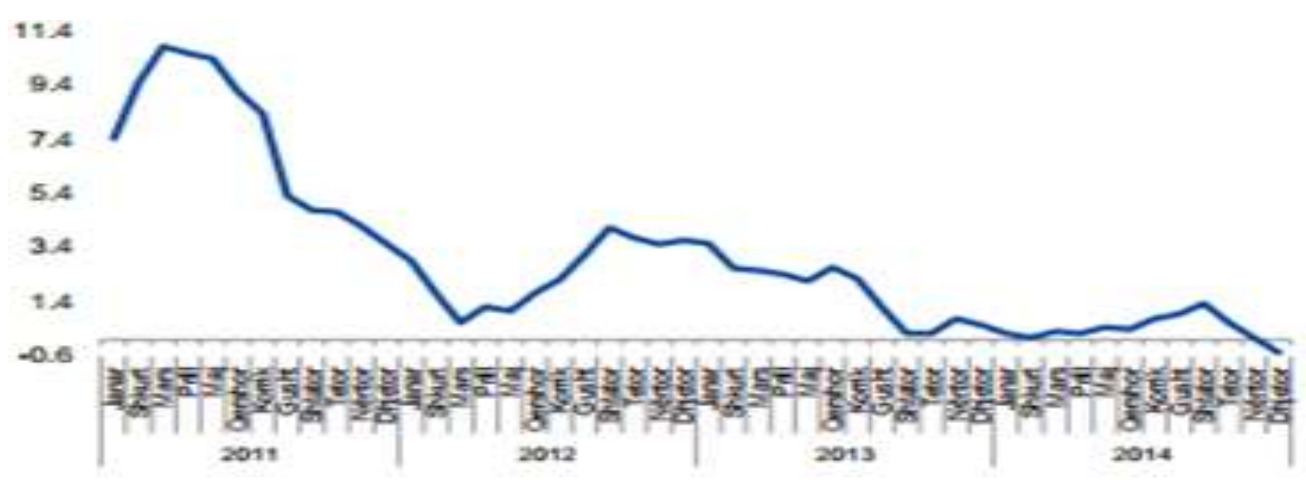

\section{Kosovo's economy}

Kosovo's economy in 2014 was characterized by slower economic activity. According to preliminary estimates of the Statistical Agency of Kosovo (ASK), the real growth rate of GDP in Kosovo was 0.9 percent, which is significantly lower than in previous years. According to estimates of the KAS, the nominal value of GDP in 2014 amounted to 5.5 billion euros. ASK estimates based on consumption and investment growth, while net exports are considered to have a negative impact on economic growth. Positive economic growth rate for 2014, but lower than the previous year's growth estimates also suggest the CBK. However, CBK estimates suggest that economic activity is based mainly on increased consumption, while investments and net exports are estimated to have contributed negatively.

On the other hand, investments which last year estimated to have declined, this year is expected to increase. Increasing domestic demand is expected to affect the growth of import and, consequently, increasing the current account deficit. While the financial account of the balance of payments is expected to improve, mainly as a 
result of increased forecasts for foreign direct investment. The price level in Kosovo, expressed by the index of consumer prices (angle: Consumer Price Index: CPI) during the second quarter of 2015 was characterized with deflation of 0.4 percent compared with inflation of 0.4 percent in the same period the year passed. During the second quarter of the year, the CPI components such as electricity, gas and other fuels prices increased an average of 4.5 percent, alcoholic beverages and tobacco 4.3 percent and 1.7 percent clothing. With the increase of 0.7 percent was also characterized food prices and soft drinks which represent about 40.9 percent of the consumer basket in Kosovo. Conversely, the more pronounced decline in prices was recorded in the services of transport to average 6.6 percent in the second quarter of 2015. The decline in the prices of transportation services is mainly attributed to the fall in the price of petroleum. The movement of prices in Kosovo is similar to the movement of prices in international markets due to the high dependence of the Kosovo economy on imports. This is shown by the behavior of similar import price index in CPI. Import prices in the first quarter of 2015 compared to the same period of the previous year fell 1.5 percent average. Within the import prices were characterized by rising prices of vegetable products, machinery and electrical equipment, paper and articles thereof, miscellaneous manufactured articles, etc. While prices of mineral products, vehicles, articles of plastics, etc., Was characterized by a decline in the first quarter of 2015. The Producer Price Index in the first quarter of 2015 versus the first quarter of 2014 marked average annual growth of 3.6 percent. The price increase was more pronounced in electricity, gas, etc., Production of wood and wood products, the production of chemical products and the production of beverages.

Indices of consumer prices, production and import

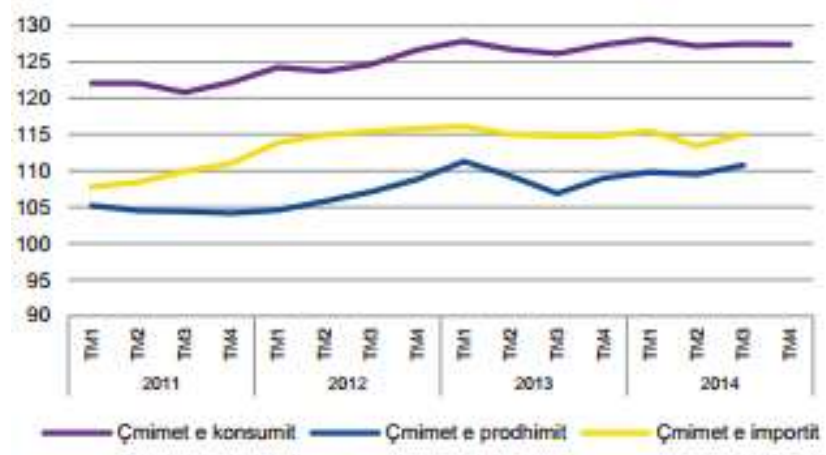

\section{Monetary policy in Kosovo}

In the past year monetary policy was characterized by a general stability, continuing the sustainability of stable money supply and inflation rate under $1 \%$

Central Bank and commercial banks have after positive balances in relation to international investment, CBK had a balance of 1.2 billion while commercial banks 482 million euro in their fund in the last year.

As regards the government trade report it $\mathrm{k}$ characterized with a negative balance of 326.4 million euro as well as other sectors of the economy that led to 1.1 billion euro in total negative balance.

The state budget is characterized by low growth from year to year, last year experienced a slight increase of $1.5 \%$ as well as budget expenditures increased at the same extent. According to these parameters Kosovo budget ended the year with a primary deficit of 130 million euro, or an average of about $2.5 \%$ of GDP.

In the period 2011-2014 Kosovo continues to have the lowest level of public debt by the end of 2014 was 10.6 which compared to the average in the countries of Eastern Europe that is $57.3 \%$ gives poultry encouragement especially in this segment.

Total public debt consists of 326.3 million international debt while the remaining EUR 256.5 million domestic debt. Despite the fact that public debt as a percentage of PBBs is low in the last two years it has increased his considerable, reflecting the growing need for financing the budget deficit. In 2014 public debt increased by 22.4 percent compared to the previous year. As shown in Figure 30, the increase of public debt is mainly attributable to the domestic debt which increased by 68.2 percent and reached 256.5 million euro, while international public debt remained almost unchanged. 


\section{Conclusions and recommendations}

The revival of the European economy, especially in the Western Balkan countries and in some of the eurozone countries is reflected in the growth of exports to Kosovo in 2014 versus the prior year. However, growth of domestic demand in the country has led to the increase of the value of total imports, thus contributing to the deterioration of the position of net exports in the country.

Balance of payments in Kosovo was characterized by growing current account deficit and capital. On the other hand, the financial account balance recorded a roughly similar previous year.

One of the main problems of Kosovo's economy remains the high level of trade deficit. Improving the trade balance requires further increase production capacity in the country and increase the competitiveness of local products both domestically and in foreign markets, as a way to improve the net export position.

\section{Kosovo's economic relations with the EU}

Since Kosovo is not a member of the European Union, it has no direct interference in the economy that conditional imposing reciprocity. Economic development depends primarily on donations as grants and other forms of financing.

Monetary measures defined by three monetary aggregates and provided by the central banks of the Member States of the European Union respectively, in coordination with the European Central Bank, Kosovo's always the fact no national currency itself

Among the priorities of the new state of Kosovo remains maximum effort to meet the conditions for membership in international organizations, regional and global level, always to be a permanent member of the great European family and the United Nations. This commitment creates prerequisites for meeting the appropriate standards for quality and competition at all levels of life that includes the field of economy.

In this regard, it is clear that Kosovo are created standards aligned with international standards in the field of legislation, competition and business climate by creating sufficient staff and quality for a European-level leadership.

The recommendations of this study would be the mobilization of citizens, businesses, scientists, students of Kosovo for integration into the EU sphere of globalization and being aware of the stage of development of Kosovo in the last decade.

Maximum efforts for meeting the European standards of quality in order to have the doors open in the European family and other international organizations.

Identification of the human resources especially our youth healthy and nationally qualified in international as well as creating a Leadership Profile "global manager"

\section{References}

[1] Charles W. Kegley, JR., World Politics, Trend and Transformation, UFO Press, Tirana, March 2009

[2] Joshua S. Goldstein, International Relations, fourth edition, Knowledge Publishing House

[3] Diaspora and Migration Policies, Forum 2015, Riinvest

[4] Monthly Statistical Bulletin, the Central Bank of the Republic of Kosovo, no. 166, June 2015

[5] Financial Stability Report, the Central Bank of the Republic of Kosovo, no. December 6, 2014.

[6] Report of the macroeconomic developments, the Central Bank of the Republic of Kosovo, no. 2, February 2015, Pristina

[7] Quarterly Economic Assessment no. 9, Quarter IV / 2014, the Central Bank of the Republic of Kosovo

[8] Kosovo Remittance Study, USAID, November 2010

[9] Financial Stability Report no. 7, Prishtina, Central Bank of the Republic of Kosovo

[10] Swiss Cooperation Office in Kosovo, the Human Development Report in Kosovo 2014

[11] Kosovo Remittance Study, UNDP 2012

[12] http://www.undp.org/content/dam/kosovo/docs/Remitances/KRS2012-Albanian-Electronic_551587.pdf

[13] http://www.itg-rks.com/sq/Ballina

[14] http://www.ks.undp.org/

[15] http://www.riinvestinstitute.org/

[16] http://www.evropaelire.org/content/article/24397436.html 
International Conference on Studies in Humanities and Social Sciences (SHSS-2015) Nov. 25-26, 2015 Paris (France)

[17] http://www.ekonomia-ks.com/?page=1,5,360384

[18] http://gazetajnk.com/?cid=1,983,1033

[19] https://ask.rks-gov.net/.../1073-studimi-mbi-remitencat

[20] http://koha.net/?id=27\&l=24635 